НАУКОВИЙ ВІСНИК

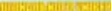

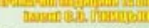

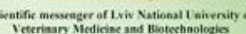

7

(1)

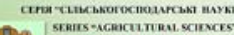

Tow 21 Nis 90

2019

Науковий вісник Дьвівського національного університету ветеринарної медицини та біотехнологій імені С.3. Гжицького.

Серія: Сільськогосподарські науки

Scientific Messenger of Lviv National University of Veterinary Medicine and Biotechnologies.

Series: Agricultural sciences

ISSN 2519-2698 print

https://nvlvet.com.ua/index.php/agriculture

doi: $10.32718 /$ nvlvet-a9018

UDC 636.598:636.084:636.03:577.112.387.4

\title{
Hematological parameters and incubation quality of eggs for different levels of tryptophan in the diet of geese of the parent flock
}

\author{
V.M. Volovich, S.A. Vovk \\ Institute of Agriculture of the Carpathian region of the National Academy of Agrarian Sciences of Ukraine, \\ Obroshino, Ukraine
}

Article info

Received 15.02.2019

Received in revised form 18.03 .2019

Accepted 19.03.2019

Institute of Agriculture of the Carpathian region of the National Academy of Agrarian Sciences of Ukraine Grushevskogo Str. 5, Obroshino, Pustomytovsky District, Lviv Region, 81115, Ukraine Tel.: +38-096-938-84-03 E-mail:v.volovych@gmail.com
Volovich, V.M., \& Vovk, S.A. (2019). Hematological parameters and incubation quality of eggs for different levels of tryptophan in the diet of geese of the parent flock. Scientific Messenger of Lviv National University of Veterinary Medicine and Biotechnologies. Series: Agricultural sciences, 21(90), 104-107. doi: 10.32718/nvlvet-a9018

The aim of the work was comparative study of the effect of various amounts of tryptophan in the diet of the herds geese on changes in the parameters of protein metabolism in the blood, their eggs laying capacity and the incubation quality of the eggs, as well as the elimination of herbs and their preservation. The research was carried out during the 4-month reproductive period (December-March) on the gray Obroshino breed group of geese in the research enterprise (SE). The experimental farm (Myklashiv) of the Myklashiv Institute of Agriculture of the Carpathian region of NAAS (Myklashiv village, Pustomytiv district, Lviv region). For this purpose, 4 groups of geese-analogues by age and live weight were selected. The control group did not receive synthetic tryptophan supplements for feed additives. The level of this amino acid in this group amounted to $0.16 \mathrm{~g}$ per $100 \mathrm{~g}$ of mixed fodder. To the diet of the geese of 2-, 3-, 4-th experimental group additionally injected, respectively, 0.04; 0.09 and 0.14 grams of synthetic tryptophan per $100 \mathrm{~g}$ of mixed fodder. The conducted studies have shown that increasing the level of tryptophan in mixed fodders of geese with respect to the norms in force in Ukraine from 0.16 to $0.25 \mathrm{~g}$ due to its synthetic analogue per $100 \mathrm{~g}$ of mixed fodder during the oviposition period increases the hemoglobin level in the blood by $0.6 \mathrm{~g} \%$, white blood cells - by $10.2 \%$, ammonium nitrogen - by $10.5 \%$, stimulates fertility and improves the quality of incubation eggs. While analyzing productivity indices of geese, it should be noted that they were the highest in the 3rd experimental group receiving an additive of 0.09 grams of synthetic tryptophan per 100 grams of mixed fodder. The isolation of the caterpillars was the highest in the $3 \mathrm{rd}$ group and amounted to $79.3 \%$. An important indicator, as the egg mass was the largest in the 3rd experimental group and was 172.7 grams or $3.1 \mathrm{~g}$ more than in the 1 st control geese group. The analysis, namely width and length, shows that the most optimal egg shape index was found in the 3rd experimental group (1.8\% higher than in the control group). The thickness of the shell of eggs in the experimental and control groups did not change significantly. It has been experimentally proved that the optimization of tryptophan levels in the feed grain of the gray Obroshin genera of geese in the reproductive period has a significant effect on the hematological parameters and the incubation quality of the eggs.

Key words: geese, gray obroshinsky breed group, feeding, tryptophan, hematological parameters, incubation qualities of eggs.

\section{Гематологічні показники та інкубаційні якості яєць за різного рівня трип- тофану в раціоні гусей батьківського стада}

\author{
В.М. Волович, С.О. Вовк
}

Інститут сільського господарства Карпатського регіону НААН Украйни, с. Оброшино Пустомитівський р-н, Львівська область, Україна 
Метою роботи було порівнювальне дослідження впливу різних кількостей триптофану в раціоні гусей батьківського стада на зміни показників білкового обміну в крові, їх несучість та інкубачійні якості яєць, а також виводимість гусенят і їх збереженість. Дослідження проведено упродовж 4-х місячного репродуктивного періоду (грудень-березень) на сірій оброшинській породній групі гусей у дослідному підприємстві (ДП) дослідне господарство (ДГ) “Миклашів” Інституту сільського господарства Карпатського регіону НААН (с. Микламів, Пустомитівський р-н, Львівської обл.). 3 иією метою було підібрано 4 групи гусей-аналогів за віком $і$ живою масою. Контрольна група не отримувала до комбікорму добавок синтетичного триптофану. Рівень иієї амінокислоти у даній групі становив 0,16 г в 100 г комбікорму. До раціону гусей 2-, 3-, 4-ї дослідної групи додатково вводили відповідно 0,04; 0,09 $i$ 0,14 г синтетичного триптофану із розрахунку на 100 г комбікорму. Проведеними дослідженнями доведено, ияо збільшення рівня триптофану в комбікормах гусей щздо чинних в Україні норм із 0,16 до 0,25 г за рахунок його синтетичного аналога із розрахунку на 100 г комбікорму в період яйцекладки підвищує рівень гемоглобіну у крові - на 0,6 г\%, лейкочитів - на 10,2\%, амінного азоту на 10,5\%, стимулює несучість та поліпшує якість інкубаиійних яєць. Аналізуючи показники продуктивності піддослідних гусей потрібно відмітити, що найвищі вони були у 3-й дослідній групі, яка отримувала добавку 0,09 гр синтетичного триптофану на 100 г комбікорму. Виводимість гусенят була найвищою у 3-й групі і становила 79,3\%. Важливий показник, як маса яйця, виявився найбільший у 3-й дослідній групі і становив 172,7 г або на 3,1 г більший ніж у 1-й контрольній групі гусей. Проведений аналіз, а саме ширини і довжини показує, щяо найбільи оптимальний індекс форми яйця виявлено у 3-й дослідній групі (на 1,8\% більший ніж у контрольній груп). Товщина шкарлупи яєщь у дослідних і контрольних групах істотно не змінювалася. Експериментально доведено, щуо оптимізація рівня триптофану в комбікормі сірої оброшинської породної групи гусей у репродуктивний період виявляє істотний вплив на гематологічні показники та інкубаційні якості яєць.

Ключові слова: гуси, сіра оброчинська породна група, годівля, триптофан, гематологічні показники, інкубаційні якості яєць.

\section{Вступ}

Численними дослідженнями доведено, що дефіцит незамінних амінокислот у раціоні птиці, зокрема гусей, призводить до порушення обміну речовин, перевитрат кормів та зниження продуктивних якостей (Arkhipov, 1984; Yastrebkov et al., 2001; Lemesheva, 2008; Podobed, 2010; Zaplatinsky \& Fedorovich, 2017; Volovich \& Vovk, 2018; Fialovych et al., 2018). Для гусей незамінними є такі амінокислоти, як валін, лейцин, ізолейцин, лізин, метіонін, треонін, триптофан, фенілаланін, гістидин та аргінін, а для гусенят - також гліцин, оскільки синтезується в організмі в обмеженій кількості (Nutrient Requirements of Poultry, 1994; Podobed, 2010; Sloboda \& Sloboda, 2018). Кожна із амінокислот виконує важливі специфічні метаболічні функції.

Щодо такої незамінної амінокислоти, як триптофан, то вона використовується в організмі гусей у біосинтезі нікотинової кислоти, серотоніну, м'язових білків, гемоглобіну, мелатоніну, $\epsilon$ необхідною для забезпечення фізіологічного перебігу овогенезу та сперміогенезу. Триптофан нормалізує роботу травної та нервової системи, стимулює імунні функції.

Незважаючи на те, що розроблені кількісні нормативи цієї амінокислоти у раціонах для різних статевих і вікових груп гусей, вітчизняні норми відрізняються від зарубіжних. Разом з тим у науковій літературі ми не виявили інформації щодо метаболічної і продуктивної дії оптимізованих кількостей триптофану в раціоні гусей у репродуктивний період.

Виходячи 3 наведеного вище, метою нашої роботи було порівнювальне дослідження впливу різних кількостей триптофану в раціоні гусей батьківського стада на зміни показників білкового обміну в крові, їх несучість та інкубаційні якості яєць, а також виводимість гусенят і їх збереженість.

\section{Матеріал і методи досліджень}

Дослідження проведено упродовж 4-місячного репродуктивного періоду (грудень-березень) на сірій оброшинській породній групі гусей у дослідному підприємстві (ДП) дослідне господарство (ДГ) “Миклашів" Інституту сільського господарства Карпатського регіону НААН (с. Миклашів, Пустомитівський рн, Львівська обл.). 3 цією метою було підібрано 4 групи гусей-аналогів за віком і живою масою. Гуси утримувались у вольєрах. Водопій вволю. У кожній групі було по 4 гуски і 1 гусаку. Гуси 1-ї контрольної групи отримували добовий раціон згідно з нормами без добавок синтетичного триптофану. Вміст даної амінокислоти у комбікормі гусей контрольної групи становив 0,16\% від маси корму. До комбікорму гусей 2-ї, 3-ї і 4-ї дослідних груп відповідно додатково вводили 0,04; 0,09 і 0,14 г синтетичного триптофану фірми “Світ Агро” (Україна). Схему досліду, склад комбікорму та його поживну цінність наведено у таблицях 1,2 і 3 .

\section{Таблиця 1}

Схема експериментального досліду

\begin{tabular}{ll}
\hline Групи гусей & Вміст триптофану в кормі (г/100г корму) \\
\hline 1-контрольна & $0,16-$ без добавки триптофану \\
2-дослідна & $0,16+0,04$ г триптофану \\
3-дослідна & $0,16+0,09$ г триптофану \\
4-дослідна & $0,16+0,14$ г триптофану \\
\hline
\end{tabular}

Таблиця 2

Склад комбікорму для гусей батьківського стада, \%

\begin{tabular}{lc}
\hline \multicolumn{1}{c}{ Компоненти } & Вміст, \% \\
\hline Пшенична дерть & 25,5 \\
Кукурудзяна дерть & 35,0 \\
Макуха соєва & 20,0 \\
Шрот соняшниковий & 6,0 \\
М’ясокісткове борошно & 5,0 \\
Вапняк & 6,0 \\
Премікс & 2,5 \\
Всього & 100 \\
\hline
\end{tabular}

Упродовж піддослідного періоду від гусей усіх груп проводили відбір яєць і визначили їх інкубаційні якості (Vlizlo et al., 2012). По завершенні експериментального періоду від 3-х гусок кожної із груп відбирали зразки крові із підкрильної вени і визначали в ній 
вміст гемоглобіну, еритроцитів, лейкоцитів, загального білка та амінного азоту (Vlizlo et al., 2012).

\section{Таблиця 3}

Вміст поживних речовин, енергії і незамінних амінокислот у 100 г комбікорму для піддослідних гусей батьківського стада контрольної групи

\begin{tabular}{lc}
\hline \multicolumn{1}{c}{ Показники } & Вміст у 100 г корму \\
\hline Обмінна енергія, мДж & 1,10 \\
Сирий протеїн, г & 16,6 \\
Сирий жир, г & 4,0 \\
Сира клітковина, г & 6,6 \\
Кальцій, г & 2,11 \\
Фосфор, г & 0,80 \\
Натрій, г & 0,30 \\
Лізин, г & 0,75 \\
Метіонін + цистин, г & 0,50 \\
Триптофан, г & 0,16 \\
\hline
\end{tabular}

Отримані цифрові дані обробляли статистично 3 використанням стандартних комп'ютерних програм Microsoft Excel.

\section{Результати та їх обговорення}

Отримані нами результати наведено у таблицях 4 i 5. 3 даних таблиці 4 видно, що у 3 дослідній групі гусей, яка отримували додатково 0,09 г синтетичного триптофану на 100 г комбікорму, істотно поліпшились гематологічні показники. Кількість гемоглобіну в крові 2-ї і 4-ї груп була вища ніж у контрольній, відповідно на 0,4 і 0,5 г\%, проте найбільшою - у 3-й дослідній групі (на 0,6\% більша ніж у контрольній групі). Також відмічається незначне збільшення еритроцитів і лейкоцитів крові у 3-ї дослідної групи гусей порівняно з контрольною. Рівень загального білка був підвищений у всіх дослідних групах, однак найвищий виявлено у 3-й групі, який становив 75,11 г/л, або був на 10,5\% вищий, ніж у контрольній групі. Що стосується рівня амінного азоту в крові, то він також найвищий у 3-й дослідній групі гусей (на 10,4\% більший, ніж у контрольній групі).

\section{Таблиця 4}

Гематологічні показники піддослідних гусей $(\mathrm{M} \pm \mathrm{m}, \mathrm{n}=3)$

\begin{tabular}{|c|c|c|c|c|}
\hline \multirow{2}{*}{ Показники } & \multicolumn{4}{|c|}{ Групи гусей } \\
\hline & 1 & 2 & 3 & 4 \\
\hline Гемоглобін, г \% & $16,5 \pm 0,12$ & $16,9 \pm 0,18$ & $17,1 \pm 0,12^{*}$ & $17,0 \pm 0,16^{*}$ \\
\hline Еритроцити, млн/1 $\mathrm{cm}^{3}$ & $4,52 \pm 0,002$ & $4,59 \pm 0,004$ & $4,54 \pm 0,004$ & $4,53 \pm 0,002$ \\
\hline Лейкоцити, тис $/ 1 \mathrm{~cm}^{3}$ & $41,9 \pm 0,25$ & $42,2 \pm 0,40$ & $42,7 \pm 0,40$ & $42,1 \pm 0,67$ \\
\hline Загальний білок, г/л & $71,12 \pm 4,8$ & $72,56 \pm 3,4$ & $75,11 \pm 3,8^{*}$ & $74,21 \pm 4,1 *$ \\
\hline Амінний азот, мг/л & $22,31 \pm 3,19$ & $23,08 \pm 2,13$ & $23,41 \pm 2,12 *$ & $23,31 \pm 1,60$ \\
\hline
\end{tabular}

Примітка: У даній і наступній таблиці зірочкою позначено вірогідність показників порівняно з контрольною групою $(*-\mathrm{P}<0,05)$

Упродовж періоду експерименту від гусей усіх піддослідних груп відбирали знесені інкубаційні яйця. Окремо у групах визначали тривалість яйцекладки, середню несучість, середню масу яйця методом зважування (Vlizlo et al., 2012), довжину та ширину яйця за допомогою штанген-циркуля. Крім цього в усіх піддослідних групах визначали індекс форми яйця (Vlizlo et al., 2012), міцність шкарлупи i товщину шкарлупи вимірювали прямим методом здавлювання (Vlizlo et al., 2012), а також виводимість гусенят. Результати вказаних досліджень наведено в таблиці 5. Аналізуючи показники продуктивності піддослідних гусей, варто зауважити, що найвищі вони були у 3-й дослідній групі, яка отримувала добавку 0,09 гр синтетичного триптофану на 100 г комбікорму. Середня несучість гусок була вищою у 2-й і 4-й групах відповідно на 0,8 і 0,9 шт. порівняно 3 контрольною, а найвищою - у 3-й дослідній групі, і становила 41,6 шт, або на 6,9 шт більша ніж у контрольній групі. Такий важливий показник, як маса яйця виявився найбільший у 3-й дослідній групі і становив 172,7 г або на 3,1 г більший ніж у 1-й контрольній групі гусей. Цей показник виявився вищим і в 2-й та 4-й групах порівняно $з$ контролем на 3,8 і 6,4 шт.

Таблиця 5

Несучість, інкубаційні якості яєць та виводимість гусенят $(\mathrm{M} \pm \mathrm{m}, \mathrm{n}=4)$

\begin{tabular}{lccc}
\hline \multicolumn{1}{c}{ Показники } & \multicolumn{3}{c}{ Групи гусей } \\
\cline { 2 - 4 } Тривалість яйцекладки, діб & 1 & 2 & 3 \\
Середня несучість гусок, шт. & $105 \pm 4,8$ & $103 \pm 3,9$ & $100 \pm 4,8$ \\
Середня маса яйця, г & $38,6 \pm 1,1$ & $39,4 \pm 1,0$ & $41,6 \pm 0,9 *$ \\
Довжина яйця, мм & $165,8 \pm 2,5$ & $169,6 \pm 2,3 *$ & $172,7 \pm 3,4 *$ \\
Ширина яйця, мм & $84,3 \pm 1,1$ & $84,8 \pm 2,0$ & $85,4 \pm 1,8$ \\
Індекс форми яйця, \% & $55,2 \pm 1,3$ & $55,8 \pm 1,2$ & $57,4 \pm 1,4 *$ \\
Міцність шкарлупи, кг/мм & $65,4 \pm 1,0$ & $65,8 \pm 1,1$ & $67,2 \pm 1,3 *$ \\
Товщина шкарлупи, мм & $2,13 \pm 0,1$ & $2,15 \pm 0,1$ & $2,16 \pm 0,3$ \\
Виводимість гусенят, \% & $0,43 \pm 0,03$ & $0,45 \pm 0,04$ & $0,44 \pm 0,05$ \\
\hline
\end{tabular}


Проведений аналіз, а саме ширини і довжини показує, що найбільш оптимальний індекс форми яйця виявлено у 3-й дослідній групі (на 1,8\% більший ніж у контрольній груп). Товщина шкарлупи яєць у дослідних і контрольних групах істотно не змінився.

Аналізуючи такий важливий показник як виводимість гусенят нами встановлено, що найвищий він був у 3-й групі і становив 79,3\%. Варто зазначити також, що вищою виявилася виводимість гусенят і у 2-й і 4-й дослідних групах, яка була відповідно на 4,0\% і 4,6\% вищою, ніж у контрольній групі птахів.

Отримані нами результати загалом узгоджуються iз дослідженнями китайських науковців (Pan et al., 2013 ) про виражений позитивний метаболічний і продуктивний ефект підвищення рівня триптофану в комбікормі гусенят Янголезкої породи 28-70 добового віку.

\section{Висновки}

Проведеними дослідженнями доведено, що збільшення рівня триптофану в комбікормах гусей щодо чинних в Україні норм із 0,16 до 0,25 г за рахунок його синтетичного аналога із розрахунку на 100 г комбікорму в період яйцекладки підвищує рівень гемоглобіну в крові на 0,6 г\%, лейкоцитів - на 10,2\%, амінного азоту - на $10,5 \%$, стимулює несучість та поліпшує якість інкубаційних яєць.

Отримані результати загалом вказують на те, що оптимізація рівня триптофану в раціоні гусей у репродуктивний період $є$ одним із важливих факторів активації метаболічних процесів в їхньому організмі, покращення гематологічних показників, підвищення несучості та поліпшення якості інкубаційних яєць.

\section{References}

Arkhipov, A.V. (1984). Protein and amino acid nutrition of the bird. Moscow (in Russian).

Fialovych, L.M., Kyryliv, Ia.I., \& Paskevych, H.A. (2018). Production of geese at using unconventional additions in mixed fodder. Scientific Messenger of Lviv National University of Veterinary Medicine and Biotechnologies. 20(84), 127-130. doi: 10.15421/nvlvet8423.

Lemesheva, M.M. (2008). Amino acid diet of the bird. Livestock Russia, 5, 30-35 (in Russian).
Nutrient Requirements of Poultry (1994). National Research Council. Washington. doi: 10.17226/2114.

Pan, X., Wei, Z., Wang, H., Yu, L., \& Liang, X. (2013). Effects of dietary tryptophan on protein metabolism and related gene expression in Yangzhou goslings under different feeding regimens. Poultry Sci., 92(12), 3196-3204. doi: 10.3382/ps.2012-02953.

Podobed, L.I. (2010). Protein and Amino Acid Food of Agricultural Bird: Structure, Sources, Optimization. Dnipropetrovsk (in Ukrainian).

Sloboda, L., \& Sloboda, O. (2018). Reproductive qualities, exterior features and the quality of the pery of obroshinsky gray geese at their dissolution "inside". Scientific Messenger of Lviv National University of Veterinary Medicine and Biotechnologies. 20(84), 137-142. doi: 10.15421/nvlvet8425.

Vlizlo, V.V. et al. (2012). Laboratory methods of research in biology, livestock and veterinary medicine. Lviv (in Ukrainian).

Volovich, V.M., \& Vovk, S.O. (2018). Changes in blood protein metabolism and reproductive qualities of geese for the use of tryptophan supplements in their diet. Materials of the 7th All-Ukrainian Scientific and Practical Conference of Young Scientists "Actual Problems of Ukrainian Agro-Industrial Production: Theory, Practice, Innovations". (Obošino village, November 6, 2018). Lviv-Obošino, 15-16 (in Ukrainian).

Volovich, V.M., \& Vovk, S.O. (2018). The productive effect of tryptophan additives to geese diet in the reproductive period. Materials of the international scientific-practical conference "Actual problems of modern biology, livestock and veterinary medecine" (Lviv, October 2018). Lviv, 103-104 (in Ukrainian).

Yastrebkov, K., Dorn, V., \& Krivenyuk, M. (2001). Trends of amino acid nutrition in poultry farming. Poultry breeding, 51, 388-390 (in Ukrainian).

Zaplatinsky, V.S., \& Fedorovich, E.I. (2017). Morphological and biochemical blood indices of obroshinsky gray and obroshinsky white natural group geese ant its depending on their physiological state. Scientific Messenger LNUVMB, 19(79), 140-144. https://nvlvet.com.ua/index.php/agriculture/article/vie w/2796. 